\title{
Distribution of Bacillus Species in Hot Cooked Foods Kept in Heating Cabinets for Consumers
}

\author{
(Received August 4, 1988)
}

\section{Kunio Shimada}

(Division of Microbiology, Public Health Institute of Hyogo Prefecture, 2-1-29, Arata-cho, Hyogo-ku, Kobe, Japan)

\begin{abstract}
Fifty samples of daily dishes (26 samples of croquettes, 10 of fried fish, 5 of hamburger steaks, 5 of meat balls and 4 of minced meat cutlets) kept hot in heating cabinets were used for a bacterial survey. Coliforms were detected in two of these foods (isolation rate $4.0 \%$ ). Forty-eight samples of these foods (96\%) were contaminated by Bacillus species, especially Bacillus licheniformis, B. subtilis, and B. coagulans.
\end{abstract}

Key words: hot cooked foods; heating cabinets; flat sour spoilage; total bacterial counts; coliforms; Staphylococcus aureus; thermophiles; Bacillus species

Some cooked daily dishes are being sold hot in open heating cabinets at supermarkets or retail stores in Japan, and are becoming increasingly used in daily life because of their convenience. Vending machines have also become popular, especially in the soft drinks industry. Nakayama and Shinya ${ }^{1), 2)}$ and York et al. ${ }^{3)}$ described the growth of thermophilic spoilage microorganisms, which produce either gaseous or flat sour spoilage in canned goods kept hot. These microorganisms thrive at the serving temperature $\left(c a .60^{\circ} \mathrm{C}\right)$ in vending machines. However, bacterial contamination of daily dishes kept hot in open heating cabinets remains obscure.

This study was done to determine the bacterial contamination of foods that are cooked, maintained in open heating cabinets, and sold throughout the day.

\section{Materials and Methods}

\section{Samples of foods}

Fifty samples of hot dishes that were obtained from October 1985 to January 1986 at several supermarkets, were examined for bacterial assay. The samples comprised 26 croquettes, 10 fried fish, 5 hamburger steaks, 5 meat balls, and 4 minced meat cutlets. They were bought just after the opening of the stores in the morning. These foods, each weighing $200 \sim 300 \mathrm{~g}$, were packaged in styrofoam boats covered with plas- tic and were kept hot in open heating cabinets that were equipped with thermometers ( $c a .40 \sim$ $65^{\circ} \mathrm{C}$ ). After their purchase, they were brought back to our laboratory in a shopping bag at the normal temperature, and they were analyzed within one hour.

Bacterial survey

A $10 \mathrm{~g}$ sample of each dish was homogenized in a sterile polyethylene bag with $90 \mathrm{ml}$ of physiological saline solution. The homogenates were used to determine total bacterial counts, coliforms and Staphylococcus aureus. Total bacterial counts were done using the standard method agar for plate counts (Nissui Ltd., Tokyo, Japan) for mesophiles and thermophiles, which were incubated for $48 \mathrm{hr}$ at $37^{\circ} \mathrm{C}$ and $55^{\circ} \mathrm{C}$, respective1y. Coliforms and $S$. aureus were determined by using the authorized method of the Food Sanitation Law in Japan, and these organisms were isolated on Salmonella Shigella Brom cresol purple (SSB) agar for Enterobacteriaceae (Nissui) and on mannitol salt agar containing egg yolk (Nissui) for S. aureus. The rest of the samples were kept hot at $55^{\circ} \mathrm{C}$ for $4 \mathrm{hr}$ and then were reassayed for thermophiles.

Isolation of Bacillus species

About ten colonies per sample from standard method agar plates were isolated randomly. These cultures were purified, grown on nutrient agar slants (Nissui) at $37^{\circ} \mathrm{C}$ and $55^{\circ} \mathrm{C}$ for $24 \mathrm{hr}$, 
Table 1. Total Bacterial Counts for Mesophiles and Detection of Coliforms and Staphylococcus aureus in Foods*1

\begin{tabular}{|c|c|c|c|c|c|c|c|c|c|}
\hline \multirow{2}{*}{ Food } & \multirow{2}{*}{$\begin{array}{l}\text { No. of } \\
\text { samples }\end{array}$} & \multicolumn{4}{|c|}{ Total bacterial counts (cells/g) } & \multicolumn{2}{|c|}{ Coliforms*2 } & \multicolumn{2}{|c|}{ S. aureus*2 } \\
\hline & & $<10$ & $10^{1 \sim 2}$ & $10^{2 \sim 3}$ & $10^{3 \sim 4}$ & + & - & + & - \\
\hline Croquette & 26 & 1 & 6 & 12 & 7 & 2 & 24 & 2 & 24 \\
\hline Fried fish & 10 & 0 & 2 & 4 & 4 & 0 & 10 & 1 & 9 \\
\hline Hamburger steak & 5 & 0 & 2 & 3 & 0 & 0 & 5 & 0 & 5 \\
\hline Meat ball & 5 & 0 & 2 & 2 & 1 & 0 & 5 & 0 & 5 \\
\hline Minced meat cutlet & 4 & 0 & 0 & 4 & 0 & 0 & 4 & 1 & 3 \\
\hline Total & 50 & 1 & 12 & 25 & 12 & 2 & 48 & $4^{* 3}$ & 46 \\
\hline
\end{tabular}

Table 2. Total Bacterial Counts for Thermophiles*1

\begin{tabular}{|c|c|c|c|c|c|c|c|}
\hline \multirow{2}{*}{ Food } & \multirow{2}{*}{$\begin{array}{l}\text { No. of } \\
\text { samples }\end{array}$} & \multicolumn{6}{|c|}{ Total bacterial counts (cells/g)*2 } \\
\hline & & $<10$ & $10^{1 \sim 2}$ & $10^{2 \sim 3}$ & $10^{3 \sim 4}$ & $10^{4 \sim 5}$ & $10^{5}<$ \\
\hline Croquette & 26 & 4 & 16 & $6(1)$ & $0(11)$ & $0(14)$ & $0(0)$ \\
\hline Fried fish & 10 & 6 & 2 & $2(2)$ & $0 \quad(5)$ & $0 \quad(1)$ & $0(2)$ \\
\hline Hamburger steak & 5 & 1 & 3 & $1(1)$ & $0 \quad(1)$ & $0 \quad(2)$ & $0(1)$ \\
\hline Meat ball & 5 & 3 & 2 & $0(3)$ & $0 \quad(2)$ & $0 \quad(0)$ & $0(0)$ \\
\hline Minced meat cutlet & 4 & 0 & 3 & $1(2)$ & $0 \quad(1)$ & $0 \quad(1)$ & $0(0)$ \\
\hline Total & 50 & 14 & 26 & $10(9)$ & $0(20)$ & $0(18)$ & $0(3)$ \\
\hline
\end{tabular}

$* 1$ The plates were incubated at $55^{\circ} \mathrm{C}$.

*2 Number of samples kept hot at $55^{\circ} \mathrm{C}$ for $4 \mathrm{hr}$ is shown in parentheses.

then clssified as either mesophile or thermophile. The isolates were further identified as Bacillus species using the following tests: Gramstain, shape, formation of spores, catalase reaction, and other conventional tests ${ }^{4) \sim 6 \text { ). }}$

\section{Results and Discussion}

\section{Bacteriai survey}

Table 1 shows total bacterial counts, coliforms, and S. aureus in food samples. According to food hygienic criteria of lunch and daily dishes in Japan, total bacterial counts are to be less than $10^{5}$ cells per gram of food, and coliforms are not to be detected. All samples met the criteria for total bacterial count: however, two of the fifty foods contained coliforms (isolation rate $4.0 \%$ ). The number of coliforms was 5 $\times 10$ and $1.2 \times 10^{2}$ per gram, respectively. One food contained Klebsiella pneumoniae and the other had Escherichia coli and Enterobacter cloacae. S. aureus was not detected by direct plating, but was found in four samples when the medium was enriched with heart infusion broth (Nissui) containing $7.5 \%$ salt. This organism produced the enterotoxins $\mathrm{A}$ and $\mathrm{B}$. This fact has resulted in special interest from food authorities, who stress the importance of intensive control of food hygiene in these foods. The results suggest that special hygienic risks, such as infections with pathogenic bacteria, need to be considered in connection with the sale of such hot cooked foods.

Thermophiles are defined as bacteria which grow at $55^{\circ} \mathrm{C}$ or over ${ }^{7), 8}$. Judging from the thermophilic bacterial counts of foods kept hot at $55^{\circ} \mathrm{C}$ for $4 \mathrm{hr}$ (Table 2), the results show that these organisms increase in number the longer the foods sit in the heating cabinets. Therefore indications not only of the date of preparation, but also of the time the food was prepared are necessary for consumers.

Isolation of Bacillus species

Five hundred and thirty-two strains were isolated from foods, and 353 of them (66.4\%) 
were identified as Bacillus. The others were gram-positive cocci, gram-negative non-sporing rods and yeasts which thrive at $37^{\circ} \mathrm{C}$, but not at $55^{\circ} \mathrm{C}$. Table 3 shows the Bacillus species of the 353 strains isolated from foods. Different Bacillus species were identified and Table 4 shows their distribution in foods. The predominant

Table 3. Bacillus Species of the 353 Strains Isolated from Foods

\begin{tabular}{lr}
\hline \hline Species & \multicolumn{2}{c}{ No. of } \\
strains (\%)
\end{tabular}

a Facultative thermophiles grow at both $37^{\circ} \mathrm{C}$ and $55^{\circ} \mathrm{C}$.

b Mesophiles grow at $37^{\circ} \mathrm{C}$, but not at $55^{\circ} \mathrm{C}$.

c Strict thermophiles grow at $55^{\circ} \mathrm{C}$, but not at $37^{\circ} \mathrm{C}$. species from foods were $B$. licheniformis, $B$. subtilis and B. coagulans. Similar results were reported in milk powder ${ }^{5}$. In general thermophiles are divided into facultative thermophiles which grow at both $37^{\circ} \mathrm{C}$ and $55^{\circ} \mathrm{C}$, and strict thermophiles which grow at $55^{\circ} \mathrm{C}$, but not at $37^{\circ} \mathrm{C}^{8}$. The facultative thermophiles isolated from foods were $B$. licheniformis, $B$. coagulans and $B$. brevis, the strict thermophiles were $B$. acidocaldarius and $B$. stearothermophilus, and the others were mesophilic Bacillus. The pathogenicities of these organisms are not yet clear (only some strains of $B$. cereus are classified as pathogens), but $10^{8}$ B. stearothermophilus per $g$ were detected in a case of food-borne illness that resulted from boiled rice that was kept hot at about $70^{\circ} \mathrm{C}$ in a rice cooker in $1979^{9}$. The presence of these bacilli may be due to the survival of heat-resistant spores in the raw materials. These may eventually result in spoilage of foods kept hot in heating cabinets; however, no cases of spoilage have yet been reported. Thermophilic bacteria, such as $B$. coagulans and B. stearothermophilus of ten can produce thermostable enzymes ${ }^{10), 11}$ and cause flat sour spoilage of foods ${ }^{1) \sim 31}$.

\section{Acknowledgments}

I am grateful to M. Kobayashi, Y. Hikasa and E. Kimura for their valuable advice in this

Table 4. Distribution of Bacillus Species in Foods

\begin{tabular}{|c|c|c|c|c|c|}
\hline \multirow{2}{*}{ Species } & \multicolumn{5}{|c|}{ No. of positive isolations (\%) in: } \\
\hline & $\begin{array}{c}\text { Croquette } \\
(n=26)\end{array}$ & $\begin{array}{l}\text { Fried fish } \\
(n=10)\end{array}$ & $\begin{array}{l}\text { Hamburger steak } \\
\qquad(n=5)\end{array}$ & $\begin{array}{l}\text { Meat ball } \\
\quad(n=5)\end{array}$ & $\begin{array}{l}\text { Minced meat cutlet } \\
\qquad(n=4)\end{array}$ \\
\hline B. licheniformis ${ }^{\mathbf{a}}$ & $20(76.9)$ & $10(100)$ & $4(80.0)$ & $3(60.0)$ & $2 \quad(50.0)$ \\
\hline B. subtilis ${ }^{\mathrm{b}}$ & $11(42.3)$ & $5 \quad(50.0)$ & $3(60.0)$ & $3(60.0)$ & $4(100)$ \\
\hline B. coagulans ${ }^{\mathrm{a}}$ & $6(23.1)$ & $2 \quad(20.0)$ & $3(60.0)$ & 0 & 0 \\
\hline B. megaterium ${ }^{\mathrm{b}}$ & $7(26.9)$ & 0 & $1(20.0)$ & 0 & 0 \\
\hline B. sphaericus ${ }^{\mathrm{b}}$ & $4(15.4)$ & 0 & $3(60.0)$ & 0 & 0 \\
\hline B. brevis ${ }^{\mathrm{a}}$ & $4(15.4)$ & 0 & 0 & $3(60.0)$ & 0 \\
\hline B. firmus $\mathrm{s}^{\mathrm{b}}$ & $5(19.2)$ & 0 & 0 & 0 & $(50.0)$ \\
\hline B. pumilus ${ }^{\mathrm{b}}$ & $2 \quad(7.7)$ & $3 \quad(30.0)$ & 0 & 0 & $(25.0)$ \\
\hline B. acidocaldarius ${ }^{\mathrm{c}}$ & $5(19.2)$ & 0 & $1(20.0)$ & 0 & 0 \\
\hline B. cereus $^{\mathrm{b}}$ & $4(15.4)$ & 0 & 0 & 0 & 0 \\
\hline B. polymyxa & $3(11.5)$ & 0 & 0 & 0 & 0 \\
\hline B. circulans $^{\mathrm{b}}$ & $2 \quad(7.7)$ & 0 & 0 & $1(20.0)$ & 0 \\
\hline B. stearothermophilus ${ }^{\mathrm{c}}$ & $2 \quad(7.7)$ & 0 & 0 & 0 & $1 \quad(25.0)$ \\
\hline B. laterosporus ${ }^{\mathrm{b}}$ & $1 \quad(3.8)$ & 0 & 0 & 0 & 0 \\
\hline
\end{tabular}

a, b, c See Table 3. 
study.

\section{References}

1) Nakayama, A., Shinya, R.: J. Food Hyg. Soc. Japan 22, 30 36 (1981).

2) Nakayama, A.: Modern Media 31, 129 150 (1985)

3) York, G. K., Heil, J. R., Marsh, G. L., Ansar, A., Merson, R. L., Wolcott, T., Leonard, S.: J. Food Sci. 40, 764 769 (1975).

4) Sakazaki, R.: "Cowan's Manual for the Identification of Medical Bacteria, Japanese, 2nd ed." p. 94 98 (1974), Kindai Publ. Co., Tokyo.

5) Jinbo, K., Kokubo, Y.: Ann. Rep. Tokyo Metr. Res. Lab. P. H. 34, 69 73 (1983).
6) Sneath, P. H. A., Mair, N. S., Sharpe, M. E., Holt, J. G. (ed.): "Bergey's Manual of Systematic Bacteriology" Volume 2, p. 1,104 1,207 (1986), The Williams \& Wilkins Co., Baltimore.

7) Brock, T. D.: "Thermophilic Microorganisms and Life at High Temperatures" p. 39 71 (1978), Springer-Verlag, New York.

8) Oshima, T.: "Thermophilic Bacteria" p. 1 170 (1978), Tokyo Univ. Publ., Tokyo.

9) Shimada, K., Nakayama, Y.: Bull. Pub. Health Inst. Hyogo Pref. 21, 40 43 (1986).

10) Hirata, H., Negoro, S., Okada, H.: Appl. Environ. Microbiol. 49, 1,547 1,549 (1985).

11) Hyun, H. H., Zeikus, J. G.: ibid. 49, 1,162 1,167 (1985) 